\title{
Integrated assessment of the impact of chemical stressors on surface water ecosystems
}

\author{
McKnight, Ursula S; Rasmussen, Jes J; Kronvang, Brian; Bjerg, Poul L; Binning, Philip J
}

\section{Published in:}

Science of the Total Environment

Link to article, DOI:

10.1016/j.scitotenv.2012.04.011

Publication date:

2012

Document Version

Peer reviewed version

Link back to DTU Orbit

Citation (APA):

McKnight, U. S., Rasmussen, J. J., Kronvang, B., Bjerg, P. L., \& Binning, P. J. (2012). Integrated assessment of the impact of chemical stressors on surface water ecosystems. Science of the Total Environment, 427-428, 319331. https://doi.org/10.1016/j.scitotenv.2012.04.011

\section{General rights}

Copyright and moral rights for the publications made accessible in the public portal are retained by the authors and/or other copyright owners and it is a condition of accessing publications that users recognise and abide by the legal requirements associated with these rights.

- Users may download and print one copy of any publication from the public portal for the purpose of private study or research.

- You may not further distribute the material or use it for any profit-making activity or commercial gain

- You may freely distribute the URL identifying the publication in the public portal 


\title{
1 Integrated assessment of the impact of chemical stressors on surface
}

\section{2 water ecosystems}

4 Ursula S. McKnight ${ }^{a^{*},}$,Jes J. Rasmussen ${ }^{\text {, }}$, Brian Kronvang ${ }^{\mathbf{b}}$, Poul L. Bjerg ${ }^{\text {a }}$, Philip

$5 \quad$ J. Binning ${ }^{\mathrm{a}}$

${ }^{a}$ Department of Environmental Engineering, Technical University of Denmark, Miljoevej Building 113, 2800 Kgs. Lyngby, Denmark

${ }^{b}$ Aarhus University, Department of Bioscience, Vejlsoevej 25, 8600 Silkeborg, Denmark

*Corresponding author: Tel.: +45 4525 1412; Fax: +45 4593 2850; E-mail: usmk@env.dtu.dk

Other author E-mail addresses: jr@dmu.dk; bkr@dmu.dk; plbj@env.dtu.dk; pjbi@env.dtu.dk

\begin{abstract}
The release of chemicals such as chlorinated solvents, pesticides and other xenobiotic organic compounds to streams, either from contaminated sites, accidental or direct application/release, is a significant threat to water resources. In this paper, different methods for evaluating the impacts of chemical stressors on stream ecosystems are evaluated for a stream in Denmark where the effects of major physical habitat degradation can be disregarded. The methods are: (i) the Danish Stream Fauna Index, (ii) Toxic Units (TU), (iii) SPEAR indices, (iv) Hazard Quotient (HQ) index and (v) AQUATOX, an ecological model. The results showed that the hydromorphology, nutrients, biological oxygen demand and contaminants (pesticides and trichloroethylene from a contaminated site) originating from groundwater do not affect the good ecological status in the stream. In contrast, the evaluation by the novel SPEAR $\mathrm{pesticides}$ index and TU indicated that the site is far from obtaining good ecological status - a direct contradiction to the ecological index currently in use in Denmark today - most likely due to stream sediment-bound pesticides arising from the spring spraying season. In order to generalise the findings of this case study, the HQ index and AQUATOX were extended for additional compounds, partly to identify potential compounds of concern, but also to determine thresholds where ecological impacts could be expected to occur. The results demonstrate that some commonly used methods for the assessment of ecological impact are not sufficient for capturing - and ideally separating - the effects of all anthropogenic stressors affecting ecosystems. Predictive modelling techniques can be especially useful in supporting early decisions on prioritising hot spots, serving to identify knowledge gaps and thereby direct future data collection. This case study
\end{abstract}


presents a strong argument for combining bioassessment and modelling techniques to multi-stressor field sites, especially before cost-intensive studies are conducted.

Key words ecological status; EU Water Framework Directive; benthic macroinvertebrates; contaminated sites; SPEAR index; AQUATOX

\section{Introduction}

Due to increasing global exploitation of both stream water and groundwater resources, it is essential to obtain a better understanding of human impacts on, and the connections between these two systems and the roles they play in maintaining water quality. Society is becoming increasingly dependent on groundwater for meeting its industrial, agricultural and domestic water needs, and anthropogenic impacts due to the release of xenobiotic organic contaminants and intensive use of agricultural chemicals has led to the degradation of this resource (Hose, 2005). To address this, the EU Water Framework Directive (WFD) requires member states to evaluate all types of contamination sources within a watershed in order to assess their direct impact on water quality and ecosystem health (Hinsby et al., 2008; Theodoropoulos and IliopoulouGeorgudaki, 2010; von der Ohe et al., 2007; Whiteman et al., 2010).

Chlorinated solvents, such as trichloroethylene (TCE), and pesticides are among the most prevalent and serious contaminants of surface and groundwater resources, particularly in industrialised countries with intensive agriculture such as Denmark (Brüsch, 2007; Danish EPA, 2010; Henriksen et al., 2008; Janniche et al., 2011). However, multiple stressors often co-exist and may interact complicating the separation and evaluation of single stressor effects in natural environments (Rasmussen et al., 2012, Wagenhoff et al., 2011; von der Ohe et al., 2011; Sánchez-Montoya et al., 2010; Thrush et al., 2008). Rasmussen et al. (2011a and 2012) showed that the effects of 
diffuse source pesticide contamination on stream macroinvertebrate communities were clouded by the effects of physical habitat degradation in Danish streams. These findings emphasise the need for field sites with good physical conditions that do not confound evaluation of the impact of other anthropogenic stressors. A suitable field site in terms of physical habitat quality was identified in McKnight et al. (2010), involving a TCE groundwater plume discharging into a stream. The majority of the catchment is used for agricultural production making the site ideal for comparing different ecological evaluation tools.

Fulfilling the requirements of the EU WFD is challenging not only because multiple occurring stressors complicate the ability to interpret results, but also because traditional approaches for managing aquatic resources often fail to account for all the potential effects of anthropogenic disturbances on the biota. Thus, the applicability of current and novel methods for determining ecological status must be re-assessed. Here we focus specifically on benthic macroinvertebrates, one of the four EU WFD biological quality elements used to characterise the ecological quality and chemical toxicity of streams, and five methods are utilised: the (i) Danish Stream Fauna Index (DSFI), (ii) Toxic Units, (iii) SPEcies At Risk (SPEAR) indices, (iv) U.S. EPA Hazard Quotient (HQ) index, and (v) an ecological model, AQUATOX, also developed by the U.S. EPA. The combined use of field indicator (bioassessment) methods and modelling techniques for the integrated assessment of anthropogenic stressors on surface water ecosystems supplies new and valuable knowledge, considering that most studies found in the literature typically encompass only one of the following: (i) results of bioassessment surveys utilizing biotic indices, such as SPEAR (see e.g. Beketov et al. (2009); Schletterer et al. (2010)), (ii) results of laboratory/microcosm studies (see e.g. 
84 Roessink et al. (2010); Weston et al. (2009)), or (iii) those which are purely modellingbased studies (see e.g. Lu et al. (2003); Sourisseau et al. (2008)). Although a few studies do exist which combine field and modelling techniques (see e.g. Feio et al. (2009); Novotny et al. (2009)), it is our opinion that these are still few and far between. Indeed, the U.S. clean water initiative of the 1990s gave a mandate for the restoration of 1000 watersheds; but the failure rate of those projects may be as high as $60 \%$, partly because they have not been based on a sound understanding of geomorphological and ecological processes (Pelley, 2000). Since predictive modelling assessments are based on changes in taxonomic composition, or deviations from "control" conditions, they may function as both early warning and compliance indicators (Norris and Hawkins, 2000). Moreover, it has long been recognized that a monitoring program should include a mechanism for determining the cause of noncompliance, and that not all diagnostic information needs to be gathered in situ especially at the stage of diagnosis (Cairns and McCormick, 1992). It is our belief that coupling "top-down" approaches (i.e. biological monitoring) with "bottom-up" strategies, such as predictive modelling techniques, can be especially useful in supporting early decisions on prioritising hot spots in time and space, and can ultimately serve to identify gaps and motivate future field work (Beketov and Liess, 2012).

The purpose of this study was to use both measured and modelled observations of contaminants and benthic macroinvertebrate communities to: (1) assess the applicability of different ecological evaluation methods for determining the impact of selected pollutants (eutrophicants, xenobiotic organic compounds and pesticides), and (2) determine threshold values and ranges for contaminant load for determining the ecological impact of pollutants by use of AQUATOX and the HQ index. We screened 
for xenobiotic organic compounds and pesticides that are (i) frequently found in groundwater and (ii) frequently used in agricultural production. The dominating land use in Denmark is agriculture (62\%) and the vast majority of streams are small in size $(<2$ metres wide), and the catchment characteristics and physical stream dimensions of the study site therefore closely resemble the general landscape enabling us to generalise our findings.

\section{Materials and Methods}

This paper considers several specific contaminants from within some broader categories of pollutants: eutrophicants (defined as substances such as nutrients that lead to rapid growth of microorganisms in surface water and resultant de-oxygenation (see e.g. Camargo and Alonso, 2006; Friberg et al., 2009); xenobiotic organic compounds (defined here as organic compounds such as chlorinated solvents and gasoline compounds originating in groundwater from contaminated sites); and pesticides (selected herbicides, insecticides and fungicides).

\subsection{Site description}

The study stream flows past the town of Lille Skensved located on Sjaelland, Denmark, with a catchment area of $25 \mathrm{~km}^{2}$, where the catchment is characterised by a low elevation, clayey/loamy soils, a temperate climate and an average regional precipitation of $500 \mathrm{~mm} \mathrm{yr}^{-1}$. The secondary aquifer at Lille Skensved is contaminated by TCE originating from an auto lacquer shop, where a leaking storage tank, found in 1993, has resulted in a plume extending up to 1,000 m downstream (Fig. 1). Although little data exists regarding the contaminant source zone, measured TCE concentrations (in the $\mathrm{mgL}^{-1}$ range) reveal the presence of a separate phase contamination and indicate that the 
source will persist for many decades. For more details on the field site geology, TCE plume and remediation history, see McKnight et al. (2010).

The stream is characterised by coarse substrate, high sinuosity and high turbulence (Supplementary material A.1 and A.2). The majority of the catchment is used for agriculture, and dominant crop types are wheat, barley and oilseed rape. In total, a 3.3 $\mathrm{km}$ stretch of the Skensved stream was surveyed to determine hydromorphological and physicochemical parameters, including in-stream vegetation and flow (stream discharge), as well as characterise benthic macroinvertebrates and xenobiotic organic compounds, as described in the following sections.

\section{Figure 1}

\subsection{Hydromorphology}

To characterise the hydromorphology of Skensved stream, for each sampling site, five cross-sectional transects at two meter intervals along the stream were surveyed and results are given in the Supplementary Material (Appendix A, Table A). At each transect, wetted width (W), depth (D) and water velocity (at $0.4 \mathrm{x}$ depth) (U) were measured at four points corresponding to $25,50,75$ and $100 \%$ of the wetted width using a flow-meter (Höntzsch $\mu \mathrm{P}-\mathrm{TAD})$. The discharge was calculated for each transect (D x $\mathrm{W} x \mathrm{U})$. Four rectangular plots were established between each pair of transects $(2 \mathrm{~m} \mathrm{x}$ $25 \%$ of wetted width). In each plot, substratum type and the total macrophyte coverage were estimated. Submergent and emergent macrophytes were identified to the lowest possible taxonomical level and proportional coverage was estimated for each taxon.

The physical habitat quality at each sampling site was assessed using the Danish Habitat Quality Index (DHQI) (Pedersen et al., 2006). The habitat survey was conducted on a $50 \mathrm{~m}$ reach that included the location for kick sampling. The DHQI 
assesses the quality of physical habitats evaluating 17 descriptors, and the final score

157

158

159

160

161

162

163

164 ranges from -12 to 63 . The threshold level for good physical habitat quality is 26 (Dunbar et al., 2010). We performed a $t$-test in order to statistically compare the DHQI scores for Skensved stream to those for the control sites $(\mathrm{P}<0.05)$.

To characterise stream flow during the sampling period, we used the 2010 hydrograph for the Lille Vejle stream (see Appendix A, Figure A) as a surrogate measure for daily discharge in Skensved stream, since no direct data for Skensved stream from 2010 exists. Lille Vejle stream is located just north (ca. $13.5 \mathrm{~km}$ ) of Skensved stream, with a catchment area of $26 \mathrm{~km}^{2}$. The daily discharge has been normalised to the size of the catchment area.

\subsection{General water chemistry}

Concentrations of oxygen and macro- and micro-nutrients in the stream water, as well as biological oxygen demand $\left(\mathrm{BOD}_{5}\right)$, conductivity, $\mathrm{pH}$ and temperature were measured at all sampling sites (see Fig. 1 and Table 1). Conductivity and oxygen concentrations were measured twice using a WTW multi-350i meter; $\mathrm{pH}$ was measured with a (YSI60) pH-meter. Water samples were collected twice in 2010 (June and August) in a wellmixed part of the stream and analysed for general water chemistry parameters, as described in more detail below.

The following parameters were analysed according to European standards: $\mathrm{BOD}_{5}$ (DS/EN 1899 1999), ortho-phosphate (DS/EN 1189-1997) and ammonia-N (DS 11732 2005). Nitrate-N was analysed using Lachat-methods (Lachat Instruments, USA, Quickchem. No. 10-107-06-33-A (Salycate method)). Chloride concentration was measured using silver nitrate (AgNO3) (Clesceri et al., 1989). Concentrations of total-N 
and total-P were measured (unfiltered samples) by the Kjeldahl-N method (Kjeldahl, 1883) and Danish standard (DS-291), respectively.

Water samples for cation analysis were immediately filtered in the field through a $0.45 \mu \mathrm{m}$ cellulose filter into $50 \mathrm{~mL}$ PE containers, preserved by addition of $4 \mathrm{M} \mathrm{HNO}_{3}$ $(\mathrm{pH}<2)$, and stored at $4^{\circ} \mathrm{C}$ until analysis. A Varian Vista MPX Axial View Inductively Coupled Plasma (ICP) OES was used for all measurements, with a Varian SPS3 auto sampler used for sample introduction. The laboratory control was prepared from 1,000 $\mathrm{mgL}^{-1}$ single element stock solution (Perkin-Elmer). Calibration solutions were prepared from $100 \mathrm{mgL}^{-1}$ multi-element standards CCS-4 and CCS-6 (Inorganic Ventures), with a calibration range of 20 to $25 \mathrm{mgL}^{-1}$. All solutions, including blanks and samples, were prepared from Milli-Q water and stabilized with $1 \% \mathrm{v} / \mathrm{v}$ concentrated nitric acid. The detection limit for calcium, magnesium and sodium was $7.05 \mu \mathrm{gL}^{-1}, 7.16 \mu \mathrm{gL}^{-1}$ for iron and manganese, and $28.09 \mu \mathrm{gL}^{-1}$ for potassium.

\subsection{Sampling of xenobiotic organic compounds and pesticides}

Samples for benzene, toluene, ethylbenzene, m-/p- and o-xylene (BTEX), naphthalene, and the chlorinated solvents PCE, TCE, trans- and cis-1,2-DCE, 1,1-DCE, 1,1-DCA and 1,1,1-TCA, were collected in $40 \mathrm{~mL}$ glass vials, at 23 locations (Fig. 1). Samples were immediately preserved using $4 \mathrm{M} \mathrm{H}_{2} \mathrm{SO}_{4}$ and stored at $4{ }^{\circ} \mathrm{C}$. The analytes were separated and identified by GC/MS using an Agilent 7980 gas chromatograph system equipped with an Agilent 5975C electron impact (70 eV) triple-axis mass-selective detector. Detection and quantification limits were determined as described by Winslow et al. (2006). The detection limit for all BTEX compounds were $0.11 \mu \mathrm{gL}^{-1}$, except m,pxylene $\left(0.22 \mu \mathrm{gL}^{-1}\right)$, and $0.14 \mu \mathrm{gL}^{-1}$ for naphthalene. Other detection limits were 0.1 $\mu \mathrm{gL}^{-1}$ for TCE, $0.05 \mu \mathrm{gL}^{-1}$ for cis-DCE, and ranged from $0.01-17.7 \mu \mathrm{gL}^{-1}$ for all other 
chlorinated compounds.

The event-triggered water sampler was deployed at sites 1 and 3 in 2010 and again at site 3 in 2011 (Fig. 1), and water samples were analysed for a broad selection of the most commonly applied herbicides, and for a series of banned herbicides most commonly found in groundwater (Table 3). During the main agricultural pesticide application season (May and June), event-controlled runoff sampling systems (Liess and von der Ohe, 2005) were used to characterise exposure to diffuse source pesticide contamination of the stream caused by heavy precipitation (defined as $\geq 10 \mathrm{~mm}$ ). Each sampler consisted of a 1-L glass bottle mounted in the main flow channel of the stream with the tube top position $5 \mathrm{~cm}$ above the water level (Liess and von der Ohe, 2005). Rising water level triggered sampling, where the bottles were then filled passively through small $(0.5 \mathrm{~cm}$ diameter) plastic tubes emerging from the bottle top.

The bottles were retrieved within 24 hours after each heavy precipitation event and stored at $4{ }^{\circ} \mathrm{C}$ until analysis. In total, four sampling events triggered the systems in 2010 and 2011. The two events in 2010 occurred on May $15^{\text {th }}$ and May $30^{\text {th }}-$ to - June $1^{\text {st }}$, with $17.5 \mathrm{~mm}$ and $13 \mathrm{~mm}$ precipitation, respectively. Additionally in 2010, grab samples were collected on August $10^{\text {th }}$ during base-flow conditions in the streams in order to characterise pesticides mainly originating from base-flow groundwater discharge. The two events in 2011 occurred on May $22^{\text {nd }}$ and June $8^{\text {th }}$, on days having $11 \mathrm{~mm}$ and $12 \mathrm{~mm}$ precipitation, respectively.

Time-integrated sampling of the bed sediment was conducted using a suspended particle sampler that was deployed in the main flow channel $10 \mathrm{~cm}$ above the stream bed at site 3 during the period from the beginning of May to the end of June 2011 (Fig. 1). The full description and mechanistic details are given in Laubel et al. (2001). 
227 Pesticide analyses for the event-controlled samplers and grab sampling were conducted by Eurofins Miljoe A/S Laboratories, and the sediment sample was analysed at the Swedish University of Agriculture (Uppsala, Sweden; Phillips et al., 2000). Analyses of all the samples were based on solid phase extraction, and the final extract was analysed by GC-MS or LC-MS. The minimum detection limit was $0.01 \mu \mathrm{gL}^{-1}$ for all pesticide compounds in water samples and $1 \mathrm{ng} \mathrm{g}^{-1}$ sediment (dry weight).

\subsection{Benthic macroinvertebrate sampling}

Benthic macroinvertebrates were sampled before (March) and after the main pesticide application season (August), using a standardised kick sampling procedure $(25 \times 25 \mathrm{~cm}$ hand net, $0.5 \mathrm{~mm}$ mesh size) (Danish EPA, 1998). Five locations were chosen along

Skensved stream (Fig. 1). At each location, four kick samples were taken across each of three transects at positions located at distances $10 \%, 50 \%, 75 \%$ and $100 \%$ from the stream bank. The 12 sub-samples were pooled into one sample and preserved in $70 \%$ ethanol. Macroinvertebrates were identified to the species level (when possible; otherwise genus) with only a few exceptions: Oligochaeta (order), Chironomidae (subfamily), Ostracoda (order), Heteroptera (family), Simuliidae (family) and Psychodidae (family) (see also Tables B.2, B.3 and B.4 in the Supplementary Material for a complete species list).

Control sites with "Least Disturbed Conditions" (Stoddard et al., 2006) in the region of Skensved stream from the Danish monitoring programme (NOVANA) were identified and data for them was extracted from the ODA database (https://oda.dk). Selection criteria were: (1) physically unmodified streams, (2) no contaminated sites or other (known) discharges impacting the stream, (3) the majority of the catchment, i.e. $>90 \%$, 
should be forest or (wet or dry) meadows and (4) the streams must have at least a good

252

253

254 ecological status according to the DSFI score (see also section 2.7.1).

Six streams fulfilled these criteria, and available data from the NOVANA database consisted of macroinvertebrate samples, characterisation of substrate, vegetation, hydrological parameters and water chemistry (see Appendix A, Table A). Data from the most recent available year (2009) was selected and includes information on benthic fauna from April, substrate and vegetation from June, and hydrological parameters and water chemistry from 2-12 dates per year. In addition, the percent cultivated area for the control sites range from $0-68 \%$, and from $13-97 \%$ for the 5 sampling sites at Skensved (see also Appendix A, Table A.1 in the supplementary material).

\subsection{Ecological assessment methods}

\subsubsection{Danish stream fauna index}

The Danish Stream Fauna Index (DSFI) is currently the method used by Denmark for the biological assessment of running waters in compliance with the EU WFD, and reports the status of oxygen sensitive species in a stream (Skriver et al., 2000). Since oxygen levels are affected by a number of contaminants, e.g. increased $\mathrm{BOD}_{5}$ or high nutrient levels, the index also provides some indication of the chemical status of a stream. The index is based on the presence/absence of a series of select species that are known to be intolerant or very tolerant to oxygen depletion (e.g. facilitated by organic pollution) (Dall and Lindegaard, 1995). The sampling procedure for DSFI is standardised, endeavouring to sample all microhabitats at a site. A DSFI index-value of 7 represents high ecological status (unpolluted conditions) under the EU WFD (European Commission, 2000); other water quality classes include good, with values of 5-6; moderate, with a value of 4; poor, with a value of 3 ; and $\mathrm{bad}$, with values of 1-2 
275 (Danish EPA, 2011). It should be noted that the DSFI converts taxonomic data into

276 index values by considering their physiological sensitivity to high $\mathrm{BOD}_{5}$, thus this

277 bioassessment metric is probably only partly independent of taxon richness and

278 diversity measures.

\subsubsection{Toxic units}

We applied toxic units (TU) as a measure for xenobiotic and pesticide toxicity,

calculating TU for all compounds detected in each sample (Tomlin, 2001). TU are

calculated according to equation 1 :

$$
T U_{(\text {D.magna })}=\log \left(C_{i} / L C 50_{i}\right)
$$

where $T U_{(D . m a g n a)}$ is the toxic unit for pesticide $i, C_{i}$ is the measured concentration of pesticide $i$ and $L C 5 O_{i}$ is the corresponding $48 \mathrm{~h}$ LC50 value for D. magna exposed to pesticide $i$. Both the maximum TU and summed TU were calculated, the latter consisting of all the compounds detected in each water sample. For summed TU, the suggested threshold value for observed acute effects in the field is $\geq-3.0$ (Liess et al.,

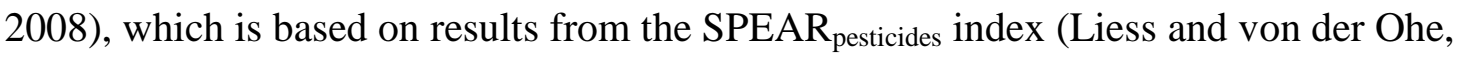
2005). The summation of all TUs is based on the principle of toxic additivity; as the number of components in a toxic mixture increases, the range of deviation from toxic additivity has been suggested to decrease (Warne and Hawker, 1995). Differences between summed concentrations of all compounds and summed TU in base-flow and storm-flow water samples were tested using t-tests.

In order to compare the potential toxicity of the pesticides that were sorbed to the sediment with the log summed TU for water samples, the log summed TU for the sediment sample was calculated. In the calculations it is necessary to account for the fact that the sorption of pesticides to organic micro-particles may reduce their acute 
toxicity to macroinvertebrates, as stated by Hill (1989) who reviewed the toxicity of pyrethroid insecticides to aquatic organisms and found that the toxicity of pyrethroids sorbed to soil particles was reduced by a factor between 100 and 600 compared to the toxicity of fully dissolved pesticides. These findings were subsequently confirmed in other studies (e.g. Maund et al., 2002; Maul et al., 2008; Schulz \& Liess 2001a, b). We therefore calculated log summed TU for sediments using equation (1). Results are presented using this range for the safety factor, noting that the lower-bound estimate is the most conservative value for decreasing the estimated ecological effect of the measured sediment concentrations.

\subsubsection{SPEcies At Risk indices}

The SPEcies At Risk indicator for pesticide contamination $\left(S_{P E A R}\right.$ pesticides) was originally developed to detect the effects of periodic pesticide contamination on stream macroinvertebrates as a result of normal agricultural practice. Macroinvertebrates are classified as being at risk or not at risk due to pesticides according to their physiological sensitivity to pesticides, life-cycle characteristics and recovery potential (Liess and von der Ohe, 2005), and is therefore independent of taxon-based data. The sampling procedure is the same as used in the DSFI. The biological traits were compiled using the freely available online SPEAR calculator

(http://www.systemecology.eu/SPEAR/index.php). After the "species at risk" were

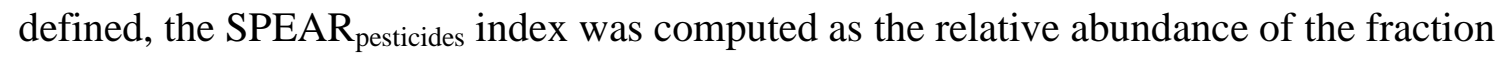
of sensitive taxa for each site, according to:

$$
\text { SPEAR } R_{\text {pesticides }}=\frac{\sum_{j=1}^{n} \log \left(x_{j}+1\right)^{*} y}{\sum_{j=1}^{n} \log \left(x_{j}+1\right)} * 100
$$

where $n$ is the number of taxa, $x_{j}$ is the abundance of the taxon $j$, and $y$ is equal to 1 if 
taxon $j$ is classified as "at risk", otherwise 0 (Beketov et al., 2009). The SPEAR pesticides index has been connected to the EU WFD categories for ecological status; the recommended threshold value characterising good ecological status is 33\% SPEAR (Beketov et al., 2009). This has been demonstrated for a range of stream types, up to 5 m, in three different biogeographical regions (Schäfer et al., 2007; Schäfer et al., 2012), and so is applicable to Skensved stream (compare Table A.1 in the Supplementary Material).

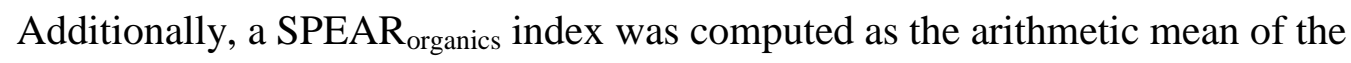
species sensitivities for all species in the sample relative to that of D. magna:

$$
S_{j}=\log \left(L C 50_{D \cdot m a g n a} / L C 50_{j}\right)
$$

where $S_{j}$ is the sensitivity of the taxon $j$. These values reflect taxon-specific sensitivity to organic contaminants in general (including both xenobiotics and pesticides), but not to a particular chemical (Beketov and Liess, 2008). Since only the physiological sensitivity of a taxon is considered for a given chemical, and not the ecological traits of

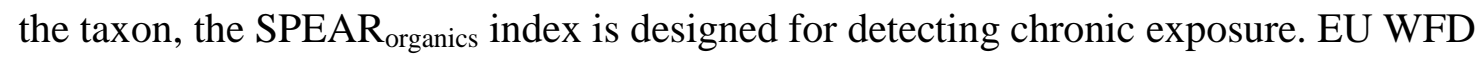
ecological status categories are currently not available for the the SPEAR organics $_{\text {index. }}$ What is evident, however, is that the more negative this index value becomes, the more serious a pollution event is with respect to the existing benthic macroinvertebrate community structure.

The temporal difference in SPEAR organics $_{\text {and }}$ SPEAR pesticides $_{\text {between the March and }}$ August samples were evaluated using a $t$-test $(\mathrm{P}<0.05, \mathrm{n}=5)$. Furthermore, we used Pearson's product moment to test the correlation between SPEAR organics $_{\text {and }}$ ane summed TU in the August base-flow samples (for pesticides, TCE and DCE), the total concentration of pesticides, and TCE and DCE in the August samples $(\mathrm{P}<0.05)$. 
346 Conformity of data with a normal distribution and homogeneity of variance were

347 confirmed prior to performing the statistical tests $(\mathrm{P}<0.05)$.

\subsubsection{Hazard quotient index}

The HQ index is applied to assess the likelihood of ecological impacts for observed concentrations in Skensved stream. The HQ method utilises the ratio (or quotient) of an exposure concentration divided by an effect concentration (equation 4), where an HQ equal to one represents the potential threshold for ecological risk (U.S. EPA, 1998), and is particularly used for chemicals where benchmark toxicity values are widely available:

$$
H Q_{i}=C_{i} / L C 50_{i}
$$

where $H Q_{i}$ is the hazard quotient for compound $i, C_{i}$ is the concentration measured or estimated at the point of exposure for compound $i$, and $L C 5 O_{i}$ is the effect concentration for compound $i$, which is a benchmark aqueous-phase toxicity value (e.g. LC50, EC50, NOAEC), and represents the dose or lethal concentration where $50 \%$ of the test population is killed. Here, the LC50 for test species representing different taxonomic groups (fish, macroinvertebrates, macrophytes and micro-algae) was chosen, as this is the benchmark utilised to produce ecotoxicology data for unknown species.

Where possible, acute ( $48 \mathrm{~h})$ toxicity values were extracted from the ECOTOX (U.S. EPA, 2011) or PAN databases (Kegley et al., 2008). If data were not available for a particular species, the web-based (and freely available) interspecies correlation estimation calculator was used (Raimondo et al., 2010), which uses least square regression to predict acute toxicity (i.e. the LC50 value) to a species, genus or family from the known toxicity of the chemical to a surrogate species. As with the TU method, we calculated the HQ for the sediment sample using the acute LC50 values for $48 \mathrm{~h}$ exposure of D. magna, but multiplied by a factor of 400 in order to account for the 
reduced toxicity with respect to expected reduced bioavailability of pesticides bound to micro-particles (see also section 2.7.2).

The HQ index is also used to determine threshold concentrations at which contaminant impacts may be observed for a selected group of compounds typically found in groundwater. Furthermore, these values were calculated for a broader range of reference species. In addition to D. magna which is widely used as the standard ecotoxicological indicator organism for chemicals in the environment (Baird et al., 1989; Vandenbrouck et al., 2010), we also included sediment feeding chironomids, predatory stoneflies (Plecoptera), and the game fish Brown trout (Salmo trutta), the latter three being found in Skensved stream whereas D. magna are normally associated with slow moving or standing waters (Allen, 1995).

\subsubsection{AQUATOX}

AQUATOX is a comprehensive, process-based ecological model for simulation of an aquatic ecosystem together with the environmental fate and effects of various pollutants, such as nutrients and organic chemicals (see Park and Clough, 2004; Park et al.,2008; Sourisseau et al., 2008, and references therein). Here the model is used to determine if measured contaminant levels result in notable changes from a control (no contaminant) system, thereby evaluating ecological impacts for the $300 \mathrm{~m}$ section of the Skensved stream impacted by the TCE groundwater plume (see also Fig. 1). AQUATOX is also used to determine threshold concentrations, specifically, concentrations where a detectable change to the modelled ecosystem occurs.

The model was calibrated to the 10-year average stream discharge data (19952004), 2005 measured TCE concentration (compare Fig. 7a in McKnight et al. (2010); Appendix C, Fig. C.1 in the supplementary material), and observed average $\mathrm{BOD}_{5}$ in 
2010 (compare Sites 2-4 in Table 1 with Fig. C.2 in Appendix C). The BOD 5 calibration was done by converting the measured $\mathrm{BOD}_{5}$ value into detritus loadings for organic matter in the water column, following equation 148b in Park and Clough (2010), then multiplying by 5 assuming $80 \%$ refractory detritus (BOD 5 represents labile detritus). It should be noted that D. magna was replaced by a compartment containing a representative species that is expected to be present at Skensved i.e. Gammarus pulex, and which fills this ecological niche (suspended feeder).

In order to better compare the AQUATOX results with actual concentrations in stream water and the HQ index, a "biomass perturbation concentration" was also determined. This value is the lowest concentration causing the predicted biomass pattern to differ significantly from the control simulation (i.e. no toxicant present), as shown by the positioning of the arrow in Fig. 4. Finally, a pseudo-sensitivity analysis - in the form of a scenario analysis - was conducted (only for TCE) to assess the dominant controls potentially affecting stream ecosystems, particularly the hydromorphological parameters. The results are available in the Supplementary Material (Appendix D).

\section{Results and Discussion}

\subsection{Field surveys of linkages between pressures and ecological quality}

\subsubsection{Hydromorphological conditions}

There was no significant difference between the average Danish Habitat Quality Index score (DHQI) for the Skensved sites compared to control sites $(\mathrm{P}>0.05)$. The sitespecific DHQI score for the Skensved sites ranged from 27 to 44, which are all above the threshold value characterising good physical habitat quality. Reduced physical habitat quality and heterogeneity, caused by heavy stream maintenance such as dredging 
and channelization that are side-effects of agricultural production, reduces the number of available types of physical habitats for macroinvertebrates (Friberg et al., 2009). The influence of poor physical habitat quality is known to reduce macroinvertebrate diversity and index scores for several macroinvertebrate indices (e.g. the ASPT and DSFI indices) (Dunbar et al., 2010; Friberg et al., 2009). Moreover, poor physical conditions has been shown to directly or indirectly reduce the SPEAR index score (Rasmussen et al., 2012). However, a DHQI score of 26 or above has been shown to be indicative of good ecological status using the DSFI index (DSFI score $\geq 5$ ) (WibergLarsen et al., 2010). Since the substratum composition and flow characteristics were not not considered to be a constraining factor for achieving good ecological status. were dominating (Fig. 2) (Kronvang and Bruhn, 1996). In contrast to the nitrate observations, phosphate-P concentrations were higher in the late summer, i.e. during low or base-flow conditions (Fig. 2), indicating that the main source of phosphate-P was 
442 local point sources (e.g. septic tanks from urban settlements) (Kronvang and Bruhn, 443 1996).

$444 \quad \mathrm{BOD}_{5}$ was highest (maximum $2.4 \mathrm{mgL}^{-1}$ ) in August at sites 3 and 4 (Fig. 1), where 445 the system is dominated by base-flow. This most likely reflects transport from the 446 groundwater deposits to the stream at these sites. In consequence, $\mathrm{BOD}_{5}$ briefly 447 increased when dilution was reduced due to the decreased discharge in August. 448 Consequently, high $\mathrm{BOD}_{5}$ at sites 3 and 4 probably only persisted for 4 to 6 weeks during the summer (see Table 1, Supplementary material A, Fig. A). Friberg et al. (2010) showed that increasing $\mathrm{BOD}_{5}$ reduced the abundance of a series of macroinvertebrate taxon groups, especially species of stoneflies (Plecoptera) and caddis 452 flies (Trichoptera). Despite a clear reduction of these species at $\mathrm{BOD}_{5}$ concentrations of 4532 to $3 \mathrm{mg} \mathrm{L}^{-1}$, all species remained present at $\mathrm{BOD}_{5}$ concentrations around $2 \mathrm{mg} \mathrm{L}^{-1}$. We therefore suggest that concentrations of $\mathrm{BOD}_{5}$ and nutrients at the study sites were of limited importance and therefore should not affect the aim of obtaining good ecological status at any of the Skensved stream sites.

The site-specific DSFI scores confirm this, as all sites were characterised by DSFI scores of 4 in March and August (Table 2) indicating no site-specific or temporal effects of $\mathrm{BOD}_{5}$. However, a DSFI score of 4 is indicative of moderate ecological status probably reflecting effects of other stressors. Since the DSFI is intended for detecting stressors (see e.g. Friberg et al., 2009). 
467 The results of the 2010 field campaign produced comparable results to the 2005 studies for TCE concentration in stream water (McKnight et al., 2010) albeit with the maximum

469 concentration being approximately 20 times lower, peaking at $0.76 \mathrm{ugL}^{-1}$ (Fig. 2), and the peak location being shifted ca. $200 \mathrm{~m}$ downstream. The fact that these values are much lower compared to the 2005 campaign is not surprising as the field site has been under hydraulic containment (pump-and-treat) since 1999.

\section{Figure 2}

In total ten different pesticides (herbicides) were detected during August base-flow conditions reflecting pesticide entry mainly via groundwater inflow (see also Appendix B, Table B for the complete list of compounds screened, detected, and their concentrations). Of the sixteen herbicides detected in total (both base-flow and stormflow water samples), five had maximum concentrations in August during base-flow, indicating groundwater inflow as an important source for pesticides in Skensved stream.

\section{Table 3}

To evaluate the chemical toxicity, the log summed TU for the groundwater-based pollutants (TCE, cis-1,2-DCE and pesticides) ranged from -4.0 to -3.7, which is an order of magnitude below the suggested threshold value (-3.0) where acute effects in the field can be expected (compare August data, Table 3). Due to the continuous input of

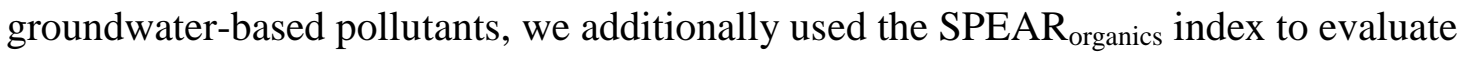
potential ecological effects (Beketov and Liess, 2008). SPEAR organics $_{\text {ranged from }-0.52}$

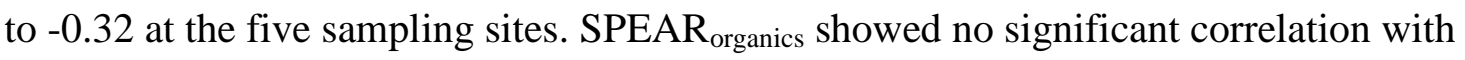
the log summed TU for the respective sites, and there was no significant difference in SPEAR $_{\text {organics }}$ between March and August samples (Table 2). Moreover, the observed 
SPEAR $_{\text {organics }}$ values for the Skensved sites are within the range previously found in uncontaminated streams (Beketov and Liess, 2008). Consequently, groundwater-based inflow of TCE, cis-1,2-DCE and pesticides should not show any detectable effects on the macroinvertebrate communities in Skensved stream.

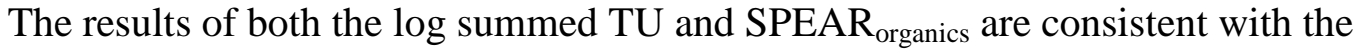
results of the HQ index (Table 3), utilising the maximum concentration detected for all compounds in stream water (see Appendix B for pesticides; Fig. 3 for xenobiotics) - for D. magna. Specifically, the HQ values for all detected concentrations were orders of magnitude below the threshold of potential for ecological risk. The herbicide dinoseb had the highest value $(\mathrm{HQ}=2.4 \mathrm{E}-04)$, and this was still four orders of magnitude below the threshold. These results showed that observed concentrations at Skensved stream for compounds originating in groundwater are far below those required for an ecological impact according to the HQ index.

\subsubsection{Pesticides related to spring spraying}

In total, 18 of the 35 pesticides screened were detected in the event-triggered water samples (Appendix B). Sixteen of the detected compounds were herbicides, the other two were fungicides; no insecticides were detected in either year. The average summed concentration of pesticides for all storm-flow samples in May/June 2010 and 2011 (0.85 $\pm 0.38 \mu \mathrm{gL}^{-1}$ ) was not significantly different from the average summed concentration for the 2010 August base-flow samples $\left(0.55 \pm 0.32 \mu \mathrm{gL}^{-1}\right)(\mathrm{P}=0.212)$. Moreover, the average log summed TU for all storm-flow samples (ranging from -4.9 to -3.6 ) was not significantly different from the average log summed TU for the August base-flow samples $(\mathrm{P}=0.714)$, and were below the threshold for expected impacts (log TU $\geq$ 3.0). The log summed TU results were again consistent with the results of the HQ index, 
calculated specifically for the pesticides detected during the spring spraying season in the stream water (May-June), indicating that the observed concentrations are orders of magnitude below the threshold of potential for ecological risk (Table 3).

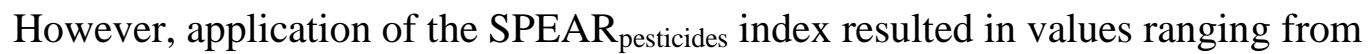

$11.1 \%$ to $19.9 \%$ SPEAR abundance in March and from $4.3 \%$ to $12.8 \%$ SPEAR abundance in August. The decrease in average $\%$ SPEAR pesticides $_{\text {abundance from before }}$ the spring pesticide spraying season (March) to after (August) was significant ( $\mathrm{P}=$ 0.002). Moreover, the $\% \mathrm{SPEAR}_{\text {pesticides }}$ abundance in the six control streams (ranging from $32.2 \%$ to $49.6 \%$, Table 2 ) was significantly higher than all SPEAR pesticides $_{\text {values }}$ in both the March and August samples from Skensved stream $(\mathrm{P}<0.001)$. Using $\mathrm{SPEAR}_{\text {pesticides }}$ as an ecological indicator tool, the temporal dynamics in the macroinvertebrate community structure clearly showed a response to the pesticide contamination, which is in direct contradiction to the results found for log summed TU and HQ for the pesticides detected in the storm-flow samples.

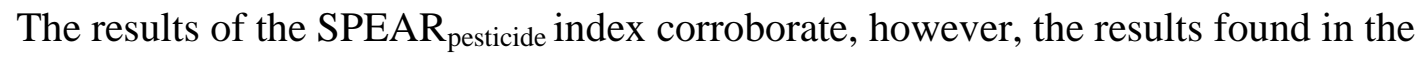
sediment sampler. Six pesticides were detected in the sediment sampled during MayJune in 2011 (Table 3); one herbicide, one fungicide and four insecticides. Both the fungicide hexachlorobenzene and the insecticide $\mathrm{HCH}$-gamma (lindane) are EU priority pollutants. The pesticides that were detected with the suspended sediment sampler have moderate to highly lipophilic physicochemical properties suggesting that they were sorbed to organic particles (Liess et al., 1996) and transported from adjacent fields, either along preferential fracture flow paths or drainage systems during heavy rain falls. with these compounds (U.S. EPA, 2011), supports our conjecture that they have most 
likely originated from spraying in the spring season or slow release from strongly-bound pesticide residues.

Moreover, the chemical toxicity calculated as the log summed TU for the sediment sample ranged from -0.14 using the most conservative factor $(=100)$ to -0.92 (factor $=$ 600), values which are more than two orders of magnitude above the threshold for expecting ecological effects in the field. In fact, this is the highest summed TU ever observed for Danish streams (compare with Rasmussen et al. 2011b, Friberg et al., 2003). Notably, the result of the TU calculation for sediment contrasted markedly with those determined by the HQ index, where values were between two and six orders of magnitude below the potential threshold for risk (Table 3). The reason for this lies in the method used to define threshold values: the HQ index threshold is based on the LC50 48h acute toxicity test values for D. magna, whereas the log TU threshold was defined

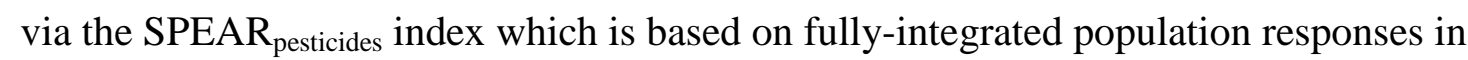
the field and therefore will be more sensitive.

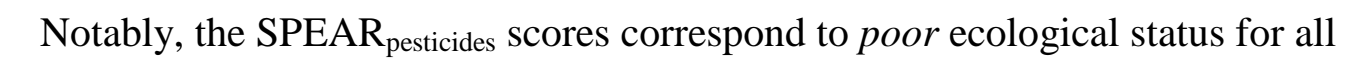
March samples and to poor-to-bad status for the August samples. Considering that the currently-used ecological indicator (DSFI) showed no temporal changes, nor a response to pesticide pollution, our results indicate that its usefulness as a bioassessment metric may be limited for xenobiotic compounds, a conclusion also reached by Friberg et al. (2009). Moreover, our results highlight the importance of considering the sediment in the evaluation of pesticides in streams.

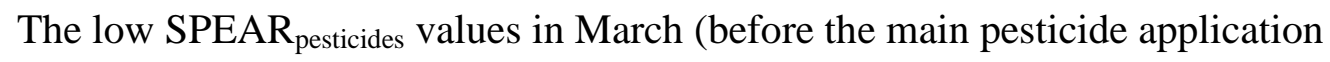
season) could reflect the fact that the macroinvertebrate community structure has adapted to several decades of agriculture in the catchment, which may have slowly 
reduced the abundance of sensitive species. Such long-lasting effects have been documented in two previous studies (Liess and von der Ohe, 2005 and von der Ohe et al., 2009). However, more field studies with high levels of temporal detail are needed to further document the long-term effects of the agricultural past.

\subsection{Evaluating the ecological impact with AQUATOX}

\subsubsection{TCE model results}

The application of the AQUATOX model in this section is undertaken to improve the understanding of TCE on the stream ecology. This forms the basis for determination of the "loading threshold range" (section 3.2.2) and extension of our results to a broader group of contaminants (section 3.3.3). Figures 3 and 4 present the ecological impact results for TCE for a variety of parameters. The calculated bioaccumulation factor (BAF) as a function of time for five species (Chironomid, Caddisfly, Mayfly, Stonefly and Brown trout) is presented and can be compared with the TCE concentration in stream water in Fig. 3a, and the TCE half-life in sediment in Fig. 3b, for a modelled timeframe of three years. Most BAF values stayed constant over the entire 3 year simulation period with two notable exceptions. The modelled fish species Brown trout consistently had an elevated value during the summer months. This was only slight for the adult species (ca. $7 \mathrm{~L} \mathrm{~kg}^{-1}$, Fig. 3a), but was quite large for the juvenile species (maximum of ca. $240 \mathrm{~L} \mathrm{~kg}^{-1}$, only depicted in Fig. 3a), corresponding to the elevated TCE concentration in stream water.

In contrast, the modelled sediment feeder Chironomid had an elevated BAF during the winter months (of ca. $35 \mathrm{~L} \mathrm{~kg}^{-1}$, Fig. 3a). The reason for this can be seen in Fig. 3b, which plots BAF versus TCE half-life in the sediment and clearly shows an elevated TCE concentration in the streambed sediment during the winter months. It should be 
noted that these results (i.e. including $\mathrm{BOD}_{5}$ calibration) are slightly different to those of McKnight et al. (2010) who presented somewhat elevated BAF values for all modelled species. However, the overall conclusions are similar to those of the earlier work. Notably, the sensitivity analysis revealed that stream discharge was found to be the factor most limiting the modelled biomass concentration for all species - pointing to the importance of hydromorphology in the obtainment of good ecological status (see also Appendix D for more specific details).

\section{Figure 3}

\subsubsection{Threshold findings for TCE}

The simulated base-case chemical loading (using the point-source loading option to input the chemical into the model) was increased (or decreased) from $5.5 \mathrm{~kg} \mathrm{yr}^{-1}$ - as measured at the site and resulting in maximum modelled TCE stream water concentrations of $10 \mu \mathrm{gL}^{-1}$ - by factors of ten in order to establish the "loading threshold range" at which toxicant stress could perturb the modelled AQUATOX ecosystem. Figure 4 presents the stream discharge and predicted biomass pattern for two species - chironomid (Fig. 4a) and stonefly (Fig. 4b) - for a modelled timeframe of three years.

The results show that there was little deviation between the control and loading scenarios for the biomass patterns of both species up to $55 \mathrm{~kg} \mathrm{yr}^{-1}$. Thus, the threshold for impact for TCE lies between 55 and $550 \mathrm{~kg} \mathrm{yr}^{-1}$ for both species, where the predicted biomass decreased by ca. $50 \%$. Results also show that stream discharge was the limiting factor most influencing the modelled biomass concentration for all species. The model thus supports the evaluation in section 3.1 by the other four methods, indicating that TCE does not affect the attainment of good ecological status in Skensved 
stream.

\section{Figure 4}

\subsubsection{Threshold findings for other compounds}

Both the AQUATOX model and the HQ index were used to generalise the findings in the case study to other compounds of interest, as well as to evaluate chemical impacts from a species-specific perspective. Specifically, the models were extended to contaminants that are typically arising from contaminated sites (benzene, PCE, and naphthalene), or pesticides found in Danish groundwater. The AQUATOX results for all compounds are presentedfor three selected organisms: Chironomid, Stonefly and Brown trout (Table 4). With respect to TCE, the "loading threshold" for all organisms ranged from $55-550 \mathrm{~kg} \mathrm{yr}^{-1}$, which is well above the actual site-specific loading determined for the site. However, PCE and naphthalene produced lower "loading threshold ranges" than TCE for at least one modelled organism. It is interesting to note that, in general, the thresholds determined for benzene, TCE, naphthalene and PCE corresponded to typical contaminant mass discharge ranges that could be expected at contaminated sites leaching into groundwater (ITRC, 2010).

The results for the "biomass perturbation concentrations" are given in Table 4.

These values can be compared with examples of concentration values currently measured in the field and reported in the literature (Table 4) and range from 0.001 to $0.023 \mathrm{mgL}^{-1}$ for xenobiotics (see e.g. Conant et al., 2004; Gomez-Belinchon et al., 1991; McKnight et al., 2010; Yamamoto et al., 1997) and from 0.001 to $0.3 \mathrm{mgL}^{-1}$ for pesticides (McKnight et al., 2011; Styczen et al., 2003). The results indicate that the compounds PCE, naphthalene and glyphosate had perturbation concentrations close to or below values actually measured in surface water. 
For comparison purposes, Table 4 also presents the HQ index results for the same

636

637

638

639

640

641

642

subset of compounds and species considered above. We first calculated HQ using a concentration that is at the high end of the range reported in the literature. MCPA and glyphosate had the highest values $(\mathrm{HQ}=0.1)$, but these were still an order of magnitude below the recommended threshold value of one. We then calculated the concentration values needed to reach the threshold and compared them to the values reported in the literature. Naphthalene had a threshold value of $0.011 \mathrm{mgL}^{-1}$, and was thereby also the closest to the actual measured and reported values in the literature, although again, it differed by an order of magnitude. PCE, MCPA, metamitron and glyphosate also had fairly low thresholds for at least one species (ranging from 0.02 to $3.0 \mathrm{mgL}^{-1}$ ), but these are still at least one order of magnitude below the threshold (MCPA), and in most cases, far below actual measured concentrations in surface water. These results suggest that contaminant concentrations have to be well above the values being reported in the literature before the HQ index will predict an ecological impact.

It is interesting to note that the HQ index results discussed above are speciesdependent. For example, the lowest threshold concentrations for naphthalene, PCE, MCPA and metamitron were obtained either for the predatory invertebrate Stonefly or for the sediment feeder Chironomid, and not for (the suspended feeder) D. magna. In fact, the pesticide glyphosate was the only compound for which the D. magna HQ threshold concentration provided the lowest (i.e. most conservative) value. This finding is worrying, considering that D. magna is often used as a standard ecotoxicological indicator.

When comparing the HQ index results to AQUATOX, it should be mentioned that, 
although the modelling in AQUATOX employs the same LC50 values that are used in the HQ calculations, the model also includes more sensitive values (i.e. EC50 growth and reproduction) to assess food web interactions. Not surprisingly, the perturbation concentrations were significantly lower than the HQ index threshold values. In about half the cases, the AQUATOX concentration thresholds were about 100 times lower than those obtained using the HQ index (compare Table 4).

\section{Implications for the EU WFD}

The results in this paper clearly demonstrate the need for re-evaluating existing ecological indices and ensuring that the best available methods are used to determine the ecological status of streams. It is essential that the indices are capable of capturing all the effects of anthropogenic stressors that could be (or have been) impacting ecosystems.

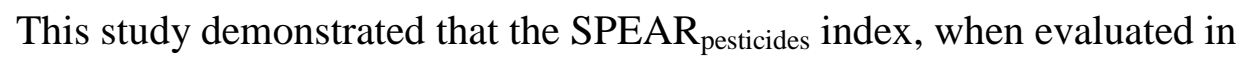
conjunction with $\mathrm{TU}$, was capable of distinguishing stressor effects, i.e. for xenobiotic

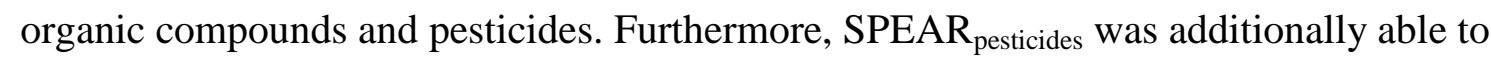
capture seasonal trends for pesticide application. Further work is still needed in order to connect the SPEAR ${ }_{\text {organics }}$ index to the EU WFD ecological classes. In contrast, the DSFI index could neither distinguish stressor effects, nor capture seasonal effects, perhaps due to the fact that its' intended use is for detecting the effects of organiccaused oxygen depletion. Others have obtained similar results, for example, the German Saprobic index - which was also constructed to detect the effects of organic pollution was less successful in capturing the effects of contaminants than SPEAR pesticides (Schletterer et al., 2010). 
It is interesting that the TU results, which are only a measure of chemical toxicity, were also capable of distinguishing stressor effects, identifying the compounds found in the sediment sample as being the only significant factor for ecological status. In contrast, the HQ index and the DSFI index were not capable of isolating this stressor.

More work is needed, however, to determine whether the calculation method applied to determine the HQ is appropriate for contaminants bound to sediment.

Our study emphasized that contaminated sites may also impact streams; although

689

690

691

692

693

694

695

696

697

698

699

700

701

702

703 no ecological effects were found, the AQUATOX model simulations showed that stream ecology may be more sensitive to changing flow conditions and other contaminants. Accordingly, it may be challenging to find an index that can truly separate and identify the most important stressors on a stream environment, but given the link between science and policy - where such indices are used by policy makers in defining water quality limits - it becomes a crucial issue (Kitsiou and Karydis, 2011).

Finally, the overall results are similar to other studies which demonstrate ecological degradation due to agro-industrial runoffs and hydromorphological alterations in streams. However, in contrast to other studies we have shown that for river restoration to be successful, risk-mitigation procedures are needed not only along the mid- and lower reaches of rivers, but also on the upper reaches. To date, the upper parts of catchments have not been considered under the WFD in most EU countries.

\section{Conclusions}

This study has shown that traditional approaches for determining ecological impact fail to account for all potential stressors affecting benthic macroinvertebrate populations in streams. In particular: 
- The hydromorphology and other general water chemistry parameters were comparable to control conditions, so these pressures are not likely to have obstructed the obtainment of good ecological status at Skensved stream. The DSFI results indicated only moderate ecological conditions, probably reflecting the effects of other stressors.

- All methods applied in this study confirmed that the xenobiotic stressor TCE, discharging into the stream from a contaminated site, did not impact benthic macroinvertebrates at measured stream concentration levels.

- Many pesticides were measured under stream base-flow conditions, indicating that groundwater inflow is an important source of pesticides to the Skensved stream. However, the methods applied (TU, SPEARorganics, HQ index, AQUATOX) could detect no significant effects to the macroinvertebrate communities. Similar results were obtained (TU, HQ index, AQUATOX) for pesticides thought to originate from the spring spraying season, at observed concentrations in the stream water.

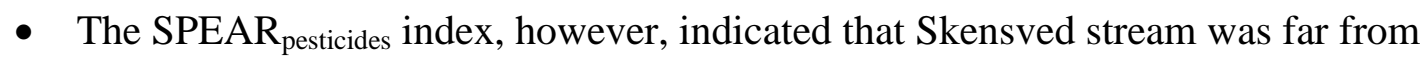
obtaining good ecological status due to pesticide contamination. We found a reduction in the abundance of species characterised as sensitive to periodic pesticide pollution (SPEAR) from before to after the main pesticide application season. Moreover, the \%SPEAR abundance was low also before the main pesticide application season, which could indicate that the macroinvertebrate communities have partly adapted to frequent disturbances in the form of pesticide input in the catchments' long history of agricultural activity.Specifically, the SPEAR pesticides $_{\text {scores corresponded to poor ecological }}$ 
status before the pesticide spraying season (March samples), and to poor-to-bad status after (August samples).

- Predictive modelling indicated that the threshold values for the investigated compounds in the water phase are much higher than the actual concentrations detected in Skensved stream (i.e. not bound to sediment). These results were suggestive that most likely the peak concentrations for pesticides in the water phase had not simply been missed, pointing to the presence of another source for the ecotoxicity. Sediment sampling at the site was motivated by these modelling observations.

- Chemical toxicity, evaluated using the TU approach in conjunction with the SPEAR $_{\text {pesticides }}$ index, identified the sediment-bound pesticides as the source for ecotoxicity, i.e. $\log$ summed TU ranged from -0.14 to -0.92 , values which are more than two orders of magnitude above the threshold for expecting ecological effects in the field; the highest ever observed value for a Danish stream.

We suggest that these results can be generalized to other sites, and although these findings are specific for the particular stream reach studied at Skensved, we believe it may be indicative for a response at the catchment-scale. However, further investigation is necessary to confirm the generality of the conclusions. In addition, a thorough analysis of historic stressors is still needed to confirm that chemical stressors dominate the ecotoxicity at this field site.

The results presented reflect the importance for identifying and implementing suitable ecological assessment methods that are capable of capturing (and ideally separating) the effects of all anthropogenic stressors potentially affecting ecosystems, in order to assess compliance with the goals of the EU WFD. Results 
demonstrate that some commonly used methods for the assessment of ecological impacts are not sufficient for this purpose. Alternatives must be considered and may lead to a determination of poorer ecological status in many surface water bodies.

757

758

759

760

761

762

763

764

765

766

767

768

769

770

771

772
Predictive modelling techniques can be especially useful in supporting early decisions on prioritising contaminated sites or streams, serving to identify knowledge gaps and thereby direct future data collection. These results are a strong argument for combining both bioassessment and modelling techniques to multistressor field sites, especially before cost-intensive studies - such as sediment sampling - are conducted.

\section{Acknowledgements}

The authors gratefully acknowledge the support of the Danish Research Council project RiskPoint (grant no. 2104-07-0035). We also thank Jonathan Clough, Dr. Richard Park and Marjorie C. Wellman for their timely advice and support with AQUATOX. We would also like to acknowledge Uffe Mensberg and Henrik Stenholt (NERI field technicians), Mikael E. Olsson and Morton Andreasen (DTU lab technicians) and Bent Skov (DTU field technician). In addition, field data was collected and supported by Nanna I. Thomsen, Maria C. Loinaz and Daniele Promio. Furthermore, we thank the three anonymous reviewers who have greatly helped to improve this manuscript. 
Allen JD. Stream Ecology. Structure and function of running waters. Dordrecht, The Netherlands: Kluwer Academic Publishers; 1995.

Baird DJ, Barber I, Bradley M, Calow P, Soares AMVM. The Daphnia bioassay: a critique. Hydrobiologia 1989; 188/189: 403-6.

Beketov MA, Liess M. An indicator for effects of organic toxicants on lotic invertebrate communities: Independence of confounding environmental factors over an extensive river continuum. Environ Pollut 2008; 156: 980-87.

Beketov MA, Foit K, Schäfer RB, Schriever CA, Sacchi A, Capri E, et al. SPEAR indicates pesticide effects in streams - Comparative use of species- and family-level biomonitoring data. Environ Pollut 2009; 157: 1841-48.

Beketov M, Liess M. 2012. Ecotoxicology and macroecology - Time for integration. Environ Pollut 2012; 162: 247-254.

Boutrup S, van der Bijl L, Jensen PN, Svendsen LM, Grant R, Bøgestrand J, Jørgensen TB, Ellemann T, Ærtebjerg G, Bruus M, Søgaard B, Thorling L, Dahlgren, K. Water quality and Nature: Condition, development and scientific compilation. National Environmental Research Institute, Aarhus University: Faglig report fra DMU Nr 646; 2007 [In Danish].

Brüsch W. Almene vandvaerkers boringskontrol af pesticider og nedbrydningsprodukter. Danish EPA: Technical Report Nr. 26; 2007 [In Danish].

Cairns J, McCormick P.V. Developing an Ecosystem-based Capability for Ecological Risk Assessments. The Environmental Professional 1992; 14, 186-196.

Camargo JA, Alonso Âl. Ecological and toxicological effects of inorganic nitrogen pollution in aquatic ecosystems: A global assessment. Environ Int 2006; 32: 831-49.

Clesceri LS, Greenberg AE, Eaton AD. Standard methods for the examination of water and wastewater. 20th edition. Washington, DC, USA: American Public Health Association; 1989.

Conant B, Cherry JA, Gillham RW. A PCE groundwater plume discharging to a river: influence of the streambed and near-river zone on contaminant distributions. J Contam Hydrol 2004; 73: 249-79.

Dall PC, Lindegaard C. An overview of Danish freshwater macroinvertebrates for the evaluation of pollution effects in lakes and streams. Copenhagen University, Denmark: Ferskvandsbiologisk Laboratorium; 1995.

Danish EPA. Biological assessment of stream water quality. Danish EPA, Ministry of Environment and Energy: Guidelines, Nr. 5; 1998 [In Danish].

Danish EPA. Bekaempelsesmiddelstatistik 2009. Danish EPA: Orientering fra Miljøstyrelsen; 2010 [In Danish].

Danish EPA. Bekendtgørelse om fastsættelse af miljømål for vandløb, søer, kystvande, overgangsvande og grundvand. Accessed: (https://www.retsinformation.dk/Forms/R0710.aspx?id=127762\#K1); November 2, 2011 [In Danish].

Dunbar MJ, Pedersen ML, Cadman D, Extence C, Waddingham J, Chadd R, Larsen SE. River discharge and local-scale physical habitat influence macroinvertebrate LIFE scores. Freshwater Biol 2010; 55:226-42.

European Commission. Establishing a framework for community action in the field of water policy. European Commission: Directive 2006/06/EC, October; 2000.

Feio MJ, Almeida SFP, Craveiro SC, Calado AJ. A comparison between biotic indices and predictive models in stream water quality assessment based on benthic diatom communities. Ecol Indic 2009; 9, 497-507. 
Friberg N, Sandin L, Pedersen ML. Assessing the Effects of Hydromorphological Degradation on Macroinvertebrate Indicators in Rivers: Examples, Constraints, and Outlook. Integrated Environmental Assessment and Management 2009; 5: 86-96.

Friberg N, Skriver J, Larsen SE, Pedersen ML, Buffagni A. Stream macroinvertebrate occurrence along gradients in organic pollution and eutrophication. Freshwater Biol 2010; 55: 1405-19.

Gomez-Belinchon JI, Grimalt JO, Albaigès J. Volatile organic compounds in two polluted rivers in Barcelona (Catalonia, Spain). Water Res 1991; 25: 577-89.

Hill, IR. Aquatic organisms and pyrethroids. Pesticide Science 1989; 27: 429-57.

Henriksen HJ, Troldborg L, Hoejberg AL, Refsgaard JC. Assessment of exploitable groundwater resources of Denmark by use of ensemble resource indicators and a numerical groundwater-surface water model. J Hydrol 2008; 348: 224-40.

Hinsby K, Condesso de Melo MT, Dahl M. European case studies supporting the derivation of natural background levels and groundwater threshold values for the protection of dependent ecosystems and human health. Sci Total Environ 2008; 401: 1-20.

Hose GC. Assessing the Need for Groundwater Quality Guidelines for Pesticides Using the Species Sensitivity Distribution Approach. Hum Ecol Risk Assess 2005; 11: 951-66.

ITRC. Use and Measurement of Mass Flux and Mass Discharge. Washington, D.C.: Interstate Technology \& Regulatory Council, Integrated DNAPL Site Strategy Team, www.itrcweb.org; 2010.

Janniche GS, Mouvet C, Albrechtsen HJ. Vertical small scale variations of sorption and mineralization of three herbicides in subsurface limestone and sandy aquifer. J Contam Hydrol 2011; 123: 167-77.

Kegley SE, Hill BR, Orme S, Choi AH. PAN Pesticide Database. North America, San Francisco, CA: Pesticide Action Network; 2008.

Kitsiou D, Karydis M. Coastal marine eutrophication assessment: A review on data analysis. Environ Int 2011; 37: 778-801.

Kronvang B, Bruhn AJ. Choice of sampling strategy and estimation method for calculating nitrogen and phosphorus transport in small lowland streams Hydrol Process 1996; 10: 1483-1501.

Laubel A, Kronvang B, Fjordback C, Larsen S. Time-integrated suspended sediment sampling from a small lowland stream. International Association of Theoretical and Applied Limnology 2001; 28: 1420-24.

Liess M, Schulz R, Neumann M. A method for monitoring pesticides bound to suspended particles in small streams. Chemosphere 1996; 32:1963-69.

Liess M, von der Ohe PC. Analyzing Effects of Pesticides on Invertebrate Communities in Streams. Environ Toxicol Chem 2005; 24: 954-65.

Liess M, Schäfer RB, Schriever CA. The footprint of pesticide stress in communities - Species traits reveal community effects of toxicants. Sci Total Environ 2008; 406:484-90.

$\mathrm{Lu} \mathrm{H}$, Axe L, Tyson TA. Development and applications of computer simulation tools for ecological risk assessment. Environmental Modeling and Assessment 2003; 8, 311-322.

Maul JD, Brennan AA, Harwood AD, Lydy MJ. Effect of sediment-associated pyrethroids, fipronil, and metabolites on Chironomus tentans growth rate, body mass, condition index, immobilization and survival. Environ Toxicol Chem 2008; 27: 2582-2590.

Maund SJ, Hamer MJ, Lane MCG, Farrelly E, Rapley JH, Goggin UM, Gentle WE. Partitioning, bioavailability, and toxicity of the pyrethroid insecticide cypermethrin in sediments. Environ Toxicol Chem 2002; 21: 9-15.

McKnight US, Funder SG, Rasmussen JJ, Finkel M, Binning PJ, Bjerg PL. An integrated model for assessing the risk of TCE groundwater contamination to human receptors and surface water ecosystems. Ecol Eng 2010; 36: 1126-37.

McKnight US, Rasmussen JJ, Kronvang B, Bjerg PL, Binning PJ. Occurrence of pesticides in surface and groundwater in two catchments on Sjaelland, Denmark. Vandkvalitet I 
grundvand/overfladevane - hvordan griber vi det an? ATV Jord og Grundvand, Mødenr. 76; 2011: 25-32. ISBN 978-87-913-13585 [In English].

Norris RH, Hawkins CP. Monitoring river health. Hydrobiologia 2000; 435, 5-17.

Novotny V, Bedoya D, Virani H, Manolakos E. Linking indices of biotic integrity to environmental and land use variables: multimetric clustering and predictive models. Water Science \& Technology 2009; 59, 1-8.

Park RA, Clough JS. AQUATOX (Release 2): Modeling Environmental Fate and Ecological Effects in Aquatic Ecosystems. Technical Documentation. U.S. EPA: Office of Water, Nr. EPA/823/R-04/002; 2004.

Park RA, Clough JS, Wellman MC. AQUATOX: Modeling environmental fate and ecological effects in aquatic ecosystems. Ecol Model 2008; 213: 1-15.

Park RA, Clough JS. AQUATOX (Release 3.1 Beta) Modeling Environmental Fate and Ecological Effects in Aquatic Ecosystems - DRAFT - Volume 2: Technical Documentation. U.S. EPA: Office of Water, Office of Science and Technology; 2010.

Pedersen ML, Sode A, Kaarup P, Bundgaard P. Habitat Quality in Danish Streams. Testing of Two Indices and Development of a National Physical Habitat Quality Index. Silkeborg: National Environmental Research Institute, Scientific Report Nr. 590; 2006 [In Danish].

Pelley J. Restoring our rivers. Envir Sci Technol 2000; February 1, 87A-90A.

Phillips JM, Russell MA, Walling DE. Time-integrated sampling of fluvial suspended sediment: a simple methodology for small catchments. Hydrol Process 2000; 14: 2589-2602.

Raimondo S, Vivian DN, Barron MG. Web-based Interspecies Correlation Estimation (WebICE) for Acute Toxicity: User Manual. Version 3.1. Gulf Breeze, FL: U.S. EPA, Office of Research and Development; 2010.

Rasmussen JJ, Baattrup-Pedersen A, Larsen SE, Kronvang B. Local physical habitat quality cloud the effect of predicted pesticide runoff from agricultural land in Danish streams. J Environ Monitor 2011a; 13: 943-50.

Rasmussen JJ, Baattrup-Pedersen A, McKnight US, Wiberg-Larsen P, Kronvang B. Buffer strip width and agricultural pesticide contamination in Danish lowland streams: Implications for stream and riparian management. Ecol Eng 2011b; 37: 1990-97.

Rasmussen JJ, Wiberg-Larsen P, Baattrup-Pedersen A, Friberg N, Kronvang B. Physical structure of stream microhabitats influences the response of stream macroinvertebrate communities to pesticide stress. Environ Pollut 2012; 164: 142-149.

Roessink I, Moermond CTA, Gillissen F, Koelmans AA. Impacts of manipulated regime shifts in shallow lake model ecosystems on the fate of hydrophobic organic compounds. Water Res 2010; 44, 6153-6163.

Sánchez-Montoya MM, Vidal-Abarca MR, Suárez ML. Comparing the sensitivity of diverse macroinvertebrate metrics to a multiple stressor gradient in Mediterranean streams and its influence on the assessment of ecological status. Ecol Indic 2010; 10: 896-904.

Schäfer RB, Caquet T, Siimes K, Mueller R, Lagadic L, Liess M. Effects of pesticides on community structure and ecosystem functions in agricultural streams of three biogeographical regions of Europe. Sci Total Environ 2007; 382: 272-85.

Schäfer R, von der Ohe P, Rasmussen J, Kefford BJ, Beketov M, Schulz R, Liess M. Thresholds for the effects of pesticides on invertebrate communities and leaf breakdown in stream ecosystems. Environ Sci Technol 2012; DOI: 10.1021/es2039882.

Schletterer M, Füreder L, Kuzovlev VV, Beketov MA. Testing the coherence of several macroinvertebrate indices and environmental factors in a large lowland river system (Volga River, Russia). Ecol Indic 2010; 10: 1083-92.

Skriver J, Friberg N, Kirkegaard J. Biological assessment of running waters in Denmark: introdution of the Danish Stream Fauna Index (DSFI). Verhandlungen des Internationalen Verein Limnologie 2000; 27: 1822-30.

Schulz R, Liess M. Toxicity of aqueous-phase and suspended particle-associated fenvalerate: Chronic effects after pulse-dosed exposure of Limnephilus lunatus (Trichoptera). Environ Toxicol Chem 2001a; 20: 185-190. 
Schulz R, Liess M. Acute and chronic effects of particle-associated fenvalerate on stream macroinvertebrates: A runoff simulation study using outdoor microcosms. Arch Environ Con Tox 2001b; 40: 481-488.

Sourisseau S, Basseres A, Perie F, Caquet T. Calibration, validation and sensitivity analysis of an ecosystem model applied to artificial streams. Water Res 2008; 42: 1167-81.

Stoddard JL, Larsen DP, Hawkins CP, Johnson RK, Norris RH. Setting Expectations for the Ecological Condition of Streams: The Concept of Reference Condition. Ecol Appl 2006; 16:1267-76.

Styczen M, Wiberg-Larsen P, Aagaard A. Tag pulsen på pesticiderne i vandmiljøet. Vand \& Jord 2003; 10(3): 84-7.

Theodoropoulos C, Iliopoulou-Georgudaki J. Response of biota to land use changes and water quality degradation in two medium-sized river basins in southwestern Greece. Ecol Indic 2010; 10: 1231-38.

Thrush SF, Hewitt JE, Hickey CW, Kelly S. Multiple stressor effects identified from species abundance distributions: Interactions between urban contaminants and species habitat relationships. J Exp Mar Bio Ecol 2008; 366: 160-68.

Tomlin CDS. The pesticide manual, a world compendium. Farnham, Surrey, UK: Crop Protection Publications; 2001.

U.S. EPA. Guidelines for Ecological Risk Assessment. Washington, DC: U.S. EPA, Risk Assessment Forum; 1998.

U.S. EPA. ECOTOX database. U.S. EPA; 2011.

Vandenbrouck T, Jones OAH, Dom N, Griffin JL, De Coen W. Mixtures of similarly acting compounds in Daphnia magna: From gene to metabolite and beyond. Environ Int 2010; 36: 254-68.

von der Ohe PC, Prüss A, Schäfer RB, Liess M, de Deckere E, Brack W. Water quality indices across Europe - a comparison of the good ecological status of five river basins. J Environ Monitor 2007; 9: 970-78.

von der Ohe PC, De Deckere E, Prüss A, Munoz I, Wolfram G, Villagrasa M, Hein M, Brack $\mathrm{W}$. Toward an integrated assessment of the ecological and chemical status of European river basins. Integrated Environmental Assessment and Management 2009; 5: 50-61.

von der Ohe PC, Dulio V, Slobodnik J, De Deckere E, Kühne R, Ebert RU, Ginebreda A, De Cooman W, Schüürmann G, Brack W. A new risk assessment approach for the prioritization of 500 classical and emerging organic microcontaminants as potential river basin specific pollutants under the European Water Framework Directive. Sci Total Environ 2011; 409: 2064-77.

Wagenhoff, A, Townsend, CR, Phillips, N, Matthaei, CD. Subsidy-stress and multiple-stressor effects along gradients of deposited fine sediment and dissolved nutrients in a regional set of streams and rivers. Freshwater Biol 2011; 56: 1916-1936.

Warne MSJ, Hawker DW. The number of components in a mixture determines whether synergistic and antagonistic or additive toxicity predominate: The Funnel hypothesis. Ecotox Environ Safe 1995; 31: 23-8.

Weston DP, Holmes RW, Lydy MJ. Residential runoff as a source of pyrethroid pesticides to urban creeks. Environ Pollut 2009; 157, 287-294.

Whiteman M, Brooks A, Skinner A, Hulme P. Determining significant damage to groundwaterdependent terrestrial ecosystems in England and Wales for use in implementation of the Water Framework Directive. Ecol Eng 2010; 36: 1118-25.

Wiberg-Larsen P, Windolf J, Baattrup-Pedersen A, Ovesen NB, Larsen SE, Thodsen H, Sode A, Kristensen E, Kjeldgaard A. Danish stream conditions, 2009. Danish EPA: Faglig raport fra DMU Nr. 804, Danmarks Miljkøundersøgelser; 2010 [In Danish].

Winslow SD, V. PB, Martin JJ, Hallberg GR, Munch DJ, Frebis CP, et al. Statistical procedures for determination and verification of minimum reporting levels for drinking water methods. Environ Sci Technol 2006; 40: 281-88. 
Yamamoto K, Fukushima M, Kakutani N, Kuroda K. Volatile organic compounds in urban rivers and their estuaries in Osaka, Japan. Environ Pollut 1997; 95: 135-43. 